\title{
Indoor Radon Concentrations in Dwellings of Ischia Island
}

\author{
Mariagabriella Pugliese $^{1,2}$, Maria Quarto ${ }^{1,2 *}$, Filomena Loffredo ${ }^{1}$, Agostino Mazzella ${ }^{3}$, Vincenzo Roca ${ }^{1,2}$ \\ ${ }^{1}$ Dipartimento di Fisica, Università di Napoli Federico II, Naples, Italy; ${ }^{2}$ Istituto Nazionale di Fisica Nucleare (INFN), Sezione di \\ Napoli, Naples, Italy; ${ }^{3}$ Liceo Statale Ischia, Naples, Italy. \\ Email: *maria.quarto@na.infn.it
}

Received June $5^{\text {th }}, 2013$; revised July $1^{\text {st }}, 2013$; accepted August $4^{\text {th }}, 2013$

Copyright (C) 2013 Mariagabriella Pugliese et al. This is an open access article distributed under the Creative Commons Attribution License, which permits unrestricted use, distribution, and reproduction in any medium, provided the original work is properly cited.

\begin{abstract}
Indoor radon concentration measurements were performed in dwellings of Ischia island (South Italy) using commercial E-Perm devices in LST configuration. The average concentrations in the dwellings were found to vary from 125 to 865 $\mathrm{Bq} / \mathrm{m}^{3}$ with an average of $354 \pm 176 \mathrm{~Bq} / \mathrm{m}^{3}$. This value is higher than Italian National average that is $75 \mathrm{~Bq} / \mathrm{m}^{3}$ and Campanian average that is $95 \mathrm{~Bq} / \mathrm{m}^{3}$. Correlation between indoor radon concentration measurements and floor level of monitored room was also studied.
\end{abstract}

Keywords: Radon; E-Perm; Floor Level

\section{Introduction}

Radon-222 and its progenies constitute the major source of natural ionizing radiation for general population. UNSCEAR [1] estimates that the annual dose from radon inhalation is responsible for $50 \%$ of the annual average dose received by people. When inhaled, radon is almost completely exhaled due to its long half-life, while its progenies, specially two radon daughters with short halflife, ${ }^{218} \mathrm{Po}$ and ${ }^{214} \mathrm{Po}$, produce alpha particles that can interact with biological tissue in the lungs leading to DNA damage [2]. Radon is considered to be the second leading cause of lung cancer after smoking and the World Health Organization [3] has established that the fraction of the lung cancer attributable to radon inhalation ranges from $3 \%$ to $14 \%$ depending on the average concentrations of the various countries and the methods of calculation. In order to limit the exposure to radon for general population, according to the Commission Recommendation 90/143/ Euratom [4], in EU countries it was established an action level of $400 \mathrm{~Bq} / \mathrm{m}^{3}$, above which radon mitigation should be made in the homes that exceed this limit. In Italy, the authorities had adopted as action level of 400 $\mathrm{Bq} / \mathrm{m}^{3}$ for existing houses and $200 \mathrm{~Bq} / \mathrm{m}^{3}$ for future buildings in accordance of international recommendation [5]. In this study, indoor radon concentration measurements in 58 dwellings of Ischia island are reported. From the geological point of view, Ischia island is very interesting, it formed successively to various eruptions in ap"Corresponding author. proximately 150,000 years. Its territories was made up of both effusive (lava flow) and explosive volcanic products (green tuff, Citara tuff) whose composition is constituted mainly by trachybasalt to latite, trachyte, alkali-trachyte and phonolite [6].

\section{Materials and Methods}

In present study, air radon measurements were carried out in 58 dwelling in Ischia island using the commercial E-Perm devices in LST configuration (Rad. Ele. Inc, Frederck, MarylandUSA) [7,8]. The measuring device consists of a $50 \mathrm{ml}$ conducting plastic chamber containing an electrostatically charged insulator (electret). Radon gas passively diffuses into the chamber through filtered inlets, and the alpha particles emitted by the radon and its daughters decay induce ionisation of air molecules. The ions produced inside chamber are collected onto surface of the electret generating a reduction of the charge of the surface. The electret charge decreases proportionally to the integrated radon concentration. The loss of the electret charge was measured by an electrometer (Rad. Ele. Inc Mod. 6383-01, Frederck, Maryland USA) and, using appropriate calibration factors and exposure time the mean radon concentration was calculated from formula:

$$
C_{R n}=\left[\frac{\left(V_{i}-V_{f}\right)}{C F^{*} T}-\left(G_{\text {gamma }} C_{1}\right)\right] \times 37
$$

where $C F=C_{2}+C_{3}\left(V_{i}+V_{f}\right) / 2$. 
$V_{i}$ and $V_{f}$ are initial and final electret voltages, respectively, $T$ is the exposure time in days, $G_{\text {gamma }}$ is the gamma background dose rate in $\mu \mathrm{Gy} / \mathrm{h}$ and $C_{1}, C_{2}$ and $C_{3}$ are constants that are given by the manufacturer and they depend on the E-Perm configuration and on the volume of the conducting plastic chamber. The mean radon concentration measured by E-Perm are sensible to indoor gamma radiation, so it is necessary to subtract the background gamma in order to avoid an overestimate of radon concentration. For this reason, the rooms where E-Perms were placed were also monitored for gamma radiation and the average gamma dose rate was found to be 0.5 $\mu \mathrm{Gy} / \mathrm{h}$. The detailed description of the method has been already described elsewhere [9]. The measurements were performed in the period 2008-2009. In each house the E-Perm detectors were exposed in the room were the resident spent most of their time, generally the bedroom or living room, in a place which is away from windows and doors, at about $1.5 \mathrm{~m}$ above the floor and $0.2 \mathrm{~m}$ distant from the wall.

\section{Results and Discussion}

The results of the radon concentrations measured in the 58 dwellings are reported in Table 1 and Figure 1.

The average radon concentration for the monitored homes were higher than Italian National average that is $75 \mathrm{~Bq} / \mathrm{m}^{3}$ [10] and Campanian average that is $95 \mathrm{~Bq} / \mathrm{m}^{3}$ [11].

Our results show that in $10 \%$ of houses, the radon concentrations are below $200 \mathrm{~Bq} / \mathrm{m}^{3}$, that is the recommended level of Italian legislation for new buildings. Furthermore, the results showed that $64 \%$ of the values were in the range $200-400 \mathrm{~Bq} / \mathrm{m}^{3}$ and $26 \%$ were higher than $400 \mathrm{~Bq} / \mathrm{m}^{3}$ which is the recommended level of Italian legislation for old building.

It is well known that some house characteristics affect the indoor radon concentration. To evaluate the dependence of radon concentration on floor level, we classified the dwellings in three groups: 1) underground, 2) ground level, and 3) equal and greater than the first floor. Anova analysis showed that there is a significant difference $(\mathrm{P}<$ 0.05 ) in mean radon concentration according to the level of the house on which the detectors was placed. From Figure 2 can be seen that that radon concentration decrease as level increases. This finding could be attributed to proximity of underground and ground level to soil that represents the main source of indoor radon and also due

Table 1. Descriptive statistics of indoor radon concentrations in monitored dwelling of Ischia island.

\begin{tabular}{cccccc}
\hline $\mathrm{N}$ & $\begin{array}{c}\mathrm{AM} \pm \mathrm{SD} \\
\left(\mathrm{Bq} / \mathrm{m}^{3}\right)\end{array}$ & $\begin{array}{c}\mathrm{GM} \\
\left(\mathrm{Bq} / \mathrm{m}^{3}\right)\end{array}$ & $\mathrm{GSD}$ & $\begin{array}{c}\text { Min } \\
\left(\mathrm{Bq} / \mathrm{m}^{3}\right)\end{array}$ & $\begin{array}{c}\mathrm{Max} \\
\left(\mathrm{Bq} / \mathrm{m}^{3}\right)\end{array}$ \\
\hline 58 & $354 \pm 176$ & 318.4 & 1.6 & 125 & 865 \\
\hline
\end{tabular}

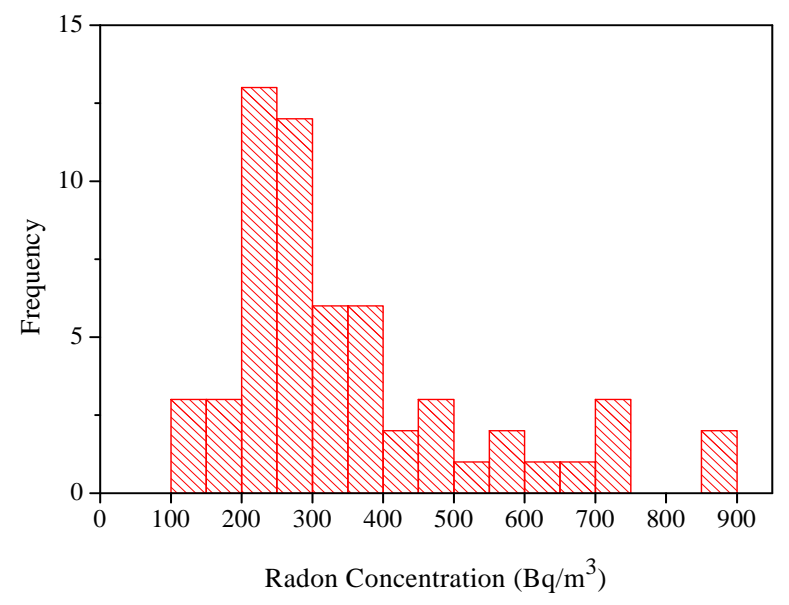

Figure 1. Distribution of radon concentrations for the 58 investigated houses of Ischia island.

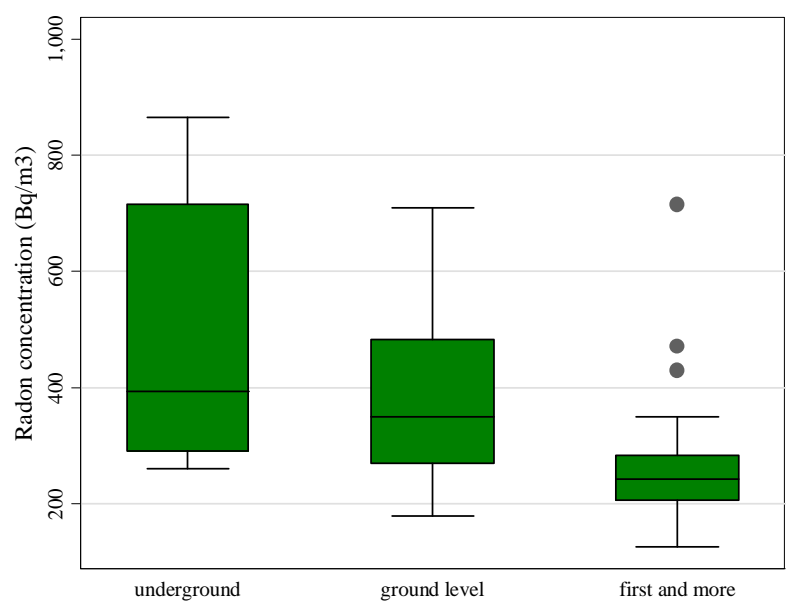

Figure 2. Variability of radon concentrations by floor level of dwellings of the Ischia island. The graph report median, $25^{\text {th }}$ and $75^{\text {th }}$ percentile; the outside values are represented by dots.

to major radon accumulation at lower floors. Moreover, the houses on the upper floors are generally exposed to greater ventilation compared to houses on the lower floors.

\section{Conclusion}

The indoor radon concentrations were measured in 58 dwellings of the Ischia island and their mean value was found to be $354 \pm 176 \mathrm{~Bq} / \mathrm{m}^{3}$. Our results show that $74 \%$ of dwellings have radon concentrations below $400 \mathrm{~Bq} / \mathrm{m}^{3}$. Moreover, a statically significant correlation between indoor radon concentrations and floor level was found.

\section{REFERENCES}

[1] United Nations Scientific Committee on the Effects of Atomic Radiations (UNSCEAR), "Report to the General Assembly with Scientific Annexes,” Annexure B., United Nations, 2000, pp. 84-156. 
[2] M. Abd El-Zaher, "Seasonal Variation of Indoor Radon Concentration in Dwellings of Alexandria City, Egypt," Radiation Protection Dosimetry, Vol. 143, No. 1, 2011, pp. 56-62. doi:10.1093/rpd/ncq357

[3] World Health Organization (WHO), "WHO Handbook on Indoor Radon: A Public Health Perspective,” World Health Organization Press, 2009.

[4] "Commission Recommendation of 21 February 1990 on the Protection of the Public against Indoor Exposure to Radon," 90/143/Euratom, European Commission-Official Journal L. 80, 1990, pp. 26-28.

[5] ICRP 65 (International Commission on Radiological Protection), "Protection against Radon-222 at Home and at Work,” Pergamon Press, Oxford, 1994.

[6] P. Frattini, B. De Vivo, A. Lima and D. Cicchella, "Elemental and Gamma-Ray Survey in the Volcanic Soil of Ischia Island, Italy," Geochemistry: Exploration, Environment, Analysis, Vol. 6, No. 4, 2006, pp. 325-339.

[7] P. Kotrappa, J. C. Dempsey, J. R. Hickey and L. R. Stieff, "An Electret Passive Environmental 222Rn Monitor Based on Ionization Measurement," Health Physics, Vol. 54, No. 1, 1988, pp. 47-56. doi:10.1097/00004032-198801000-00002

[8] P. Kotrappa, J. C. Dempsey, R. W. Ramsey and L. R.
Stieff, “A Practical E-PERM (Electret Passive Environmental Radon Monitor) System for Indoor 222Rn Measurement," Health Physics, Vol. 58, No. 4, 1988, pp. 461467. doi:10.1097/00004032-199004000-00008

[9] M. Pugliese, M. Quarto and V. Roca, "Radon Concentrations in Air and Water in the Thermal Spas of Ischia Island,” Indoor and Built Environment. doi:10.1177/1420326X13480053

[10] F. Bochiccio, G. Campos Venuti, C. Nuccetelli, S. Piermattei, S. Risica, L. Tommasino and G. Torri, "Results of the Representative Italian National Survey on Radon Indoors,” Health Physics, Vol. 71, No. 5, 1996, pp. 741-748. doi:10.1097/00004032-199611000-00016

[11] F. Bochicchio, G. Campos Venuti, S. Piermattei, C. Nuccetelli, S. Risica, L. Tommasino, G. Torri, M. Magnoni, G. Agneso, G. Sgorbati, M. Bonomi, L. Minach, F. Trotti, M. R. Malisan, S. Maggiolo, L. Gaidolfi, C. Giannardi, A. Rongoni, M. Lombardi, G. Cherubini, S. D’Ostilio, C. Cristofaro, M. Pugliese, V. Martucci, A. Crispino, P. Cuzzocrea, A. Sansone Santamaria and M. Cappai, “Annual Average and Seasonal Variations of Residential Radon Concentration for All the Italian Regions," Radiation Measurements, Vol. 40, No. 2-6, 2005, pp. 686-694. doi:10.1016/j.radmeas.2004.12.023 